\title{
Isolation, Sequence Analysis, and Linkage Mapping of Nucleotide Binding Site-Leucine-rich Repeat Disease Resistance Gene Analogs in Watermelon
}

\author{
Karen R. Harris ${ }^{1}$, W. Patrick Wechter, and Amnon Levi ${ }^{2}$ \\ USDA-ARS, U.S. Vegetable Laboratory, 2700 Savannah Highway, Charleston, SC 29414
}

\begin{abstract}
Additional INDEX words. Citrullus lanatus, TIR, degenerate primers, Cucurbitaceae, STS
Abstract. Sixty-six watermelon (Citrullus lanatus var. lanatus) disease resistance gene analogs were cloned from 'Calhoun Gray', PI 296341, and PI 595203 using degenerate primers to select for the nucleotide binding sites (NBS) from the NBS-leucine-rich repeat (LRR) resistance gene family. After contig assembly, watermelon resistance gene analogs (WRGA) were identified and amino acid sequence alignment revealed that these groups contained motifs characteristic of NBS-LRR resistance genes. Using cluster analysis, eight groups of WRGA were identified and further characterized as having homology to Drosophila Toll and mammalian interleukin-1 receptor (TIR) and nonTIR domains. Three of these WRGA as well as three disease-related watermelon expressed sequence tag homologs were placed on a test-cross map. Linkage mapping placed the WRGA on linkage group XIII, an area on the watermelon map where resistance gene analogs cluster. In addition, these WRGA sequence-tagged sites (STS) were amplified from various genera of the Cucurbitaceae indicating that conservation of resistance gene analogs exists among cucurbits. These WRGA-STS markers may be useful in marker-assisted selection for the improvement for disease resistance in watermelon.
\end{abstract}

Like with many vegetable crops, U.S. watermelon cultivars have been bred for a fairly narrow set of horticultural traits suitable to the needs of growers, shippers, and consumers. These highly specific breeding efforts have resulted in $92 \%$ to $99 \%$ genetic similarity among U.S. watermelon cultivars (Levi et al., 2001). Although this narrow genetic base provides for a consistent product, it leaves the crop vulnerable to existing and emerging plant pests and diseases (phytopathogens), including viruses, fungi, oomycetes, bacteria, and insects.

The most destructive virus diseases in watermelon are caused by papaya ringspot virus, watermelon mosaic virus, and zucchini yellow mosaic virus (Strange et al., 2002). The most devastating fungal and bacterial diseases include fusarium wilt caused by the fungus Fusarium oxysporum f. sp. niveum (Zhou and Everts, 2004) and bacterial fruit blotch caused by Acidovorax avenae ssp. citrulli (Hopkins et al., 2003). In addition, watermelon cultivars also are typically susceptible to root-knot nematodes (Meloidogyne arenaria, M. incognita, M. javanica) (Thies and Levi, 2007), to arthropods including two-spotted spider-mite (Tetranychus urticae) (Lopez et al., 2005), and to sweetpotato whitefly (Bemisia tabaci) (Simmons and Levi, 2002). To provide adequate levels of resistance to these diseases and other pests, introgression of resistance genes from semiexotic watermelon accessions (e.g., C. lanatus var. citroides, Citrullus colocynthis) into cultivated watermelon is

Received for publication 14 Sept. 2009. Accepted for publication 23 Oct. 2009 We thank Ellis Caniglia, Ryan Donahoo, and Jay Coady for their technical assistance and Dr. Robert Jarret for critical reading of the manuscript.

Mention of trade names or commercial products in this article is solely for the purpose of providing specific information and does not imply recommendations or endorsement by the U.S. Department of Agriculture.

${ }^{1}$ Current address: USDA-ARS, Crop Genetics and Breeding Research Unit, 115 Coastal Way, Tifton, GA 31793

${ }^{2}$ Corresponding author. E-mail: Amnon.Levi@ars.usda.gov. needed. Despite many inheritance studies on pathogen resistance in watermelon (Wehner, 2008), little is known about the structural makeup and functional mechanisms of genes that confer resistance, and only a few genetic markers linked to resistance genes have been identified in watermelon (Harris et al., 2009; Ling et al., 2009; Xu et al., 1999).

Disease resistance genes (R-genes) have been cloned from several model plant species (reviewed in McHale et al., 2006). Of the $\approx 40$ R-genes known to confer resistance to bacteria, fungi, viruses, and nematode phytopathogens, $75 \%$ encode nucleotide binding site-leucine-rich repeat (NBS-LRR) proteins (Radwan et al., 2008). In dicots, NBS-LRR proteins are classified into two subgroups. One subgroup of these NBS-LRR proteins possesses a domain with significant homology to the Drosophila Toll and mammalian interleukin-1 receptor (TIR) region, whereas the other subgroup is defined by the presence of an aminoterminal region containing a coiled-coil (CC) motif (Gowda et al., 2002). Alternatively, the CC domain can be joined or replaced with a Solanaceae domain or a BEAF and DREF (BED) DNA binding domain (Collier and Moffett, 2009).

The exact mechanisms by which these NBS-LRR proteins detect a pathogen attack are not known, but both direct and indirect contact with avirulence factors may be involved (DeYoung and Innes, 2006). Although a direct interaction of the NBS-LRR protein with the pathogen-secreted effector molecules has been detected in a few studies, this interaction may be the exception rather than the rule (Deslandes et al., 2003; Jia et al., 2000). To address the fact that a relatively small number of resistance gene analogs have been identified when compared with the vast number of pathogens and their associated plethora of races, pathoclasses, and so on, the "guard hypothesis" was proposed. The guard hypothesis represents an indirect interaction scheme whereby NBS-LRR proteins act as sentinels. Under this hypothesis, the NBS-LRR proteins 
monitor plant proteins that are targets of pathogen effectors rather than the effector molecules themselves (Van der Biezen and Jones, 1998). A recent alternative model, the "bait and switch" model, describes a host bait protein that interacts with the NBS-LRR (Collier and Moffett, 2009). When a pathogen Avr protein interacts with the bait (which is bound to the NBSLRR) through direct binding or alteration of the bait, a switch is flipped and the complex then interacts with downstream signaling components.

The mining of resistance gene analogs from numerous plant genomes has been accomplished using the polymerase chain reaction (PCR) and degenerate primers that target regions within the NBS domain (Cordero and Skinner, 2002; Deng et al., 2000; Gowda et al., 2002; Nair and Thomas, 2007; Radwan et al., 2008). The NBS domain includes the P-loop, kinase-2 motif, and kinase-3a motif as well as conserved blocks of unknown function, which include RNBS-A, RNBS-C, GLPL, RNBS-D, and MHD (De Young and Innes, 2006). Many of these resistance gene analogs (RGAs) have been linked to gene loci that confer resistance to phytopathogens (Deng et al., 2000) and appear to be clustered in a number of plant genomes (Brotman et al., 2002). In this study, we aimed to clone, characterize, and map a collection of watermelon resistance gene analogs (WRGA) by using degenerate primers that target the NBS region from watermelon genotypes $C$. lanatus var. citroides and C. lanatus var. lanatus possessing resistance to fusarium wilt and several watermelon viruses.

\section{Materials and Methods}

Mining the Cucurbit eXPressed Sequence tag databases FOR HOMOLOGS OF GENES INVOLVED IN DISEASE RESISTANCE. Watermelon expressed sequence tag (EST) unigenes (Levi et al., 2006) with homology to genes found to be involved in disease resistance in other genera were identified in the watermelon EST database (International Cucurbit Genomics Initiative, 2009). PCR primers were designed from these potential disease resistance ESTs [Supplemental Table 1 (available online with the electronic version of this article), primers labeled with the International Cucurbit Genomics Initiative designation "WMU"]. These primers were used to screen for polymorphism in the parents of a watermelon testcross mapping population previously developed and described by Levi et al. (2006). The parents were Griffin 14113, 'New Hampshire Midget' (NHM), and PI 386015. PCR primers were multiplexed in a $20-\mu \mathrm{L}$ reaction volume with the following components: $4 \mu \mathrm{L}$ of Promega GoTaq ${ }^{\circledR}$ Flexi $5 \times$ PCR buffer (Promega, Madison, WI), $1.2 \mu \mathrm{L}$ of $25 \mathrm{~mm} \mathrm{MgCl}_{2}, 1.6 \mu \mathrm{L}$ of $2.5 \mathrm{~mm}$ dNTP mix, $3 \mu \mathrm{L}$ of M13 primer fluorescently labeled with D4, $0.5 \mu \mathrm{L}$ of M13 tagged forward primers WMU1502-F, WMU2175-F, and WMU2837-F, $0.6 \mu \mathrm{L}$ of WMU1502-R, WMU2175-R, and WMU2837-R (Supplemental Table 1), 0.2 $\mu \mathrm{L}$ of Promega GoTaq ${ }^{\circledR}$ DNA polymerase (Promega), $4.7 \mu \mathrm{L}$ of water, and $2 \mu \mathrm{L}$ of DNA at $10 \mathrm{ng} \cdot \mu \mathrm{L}^{-1}$. Thermocycling conditions were 40 cycles of $95^{\circ} \mathrm{C}$ for $1 \mathrm{~min}, 57^{\circ} \mathrm{C}$ for $1 \mathrm{~min}$, and $72^{\circ} \mathrm{C}$ for $1 \mathrm{~min}$. PCR products were resolved on a Beckman CEQ 8800 Genetic Analysis System (Beckman Coulter, Fullerton, CA) using the fragment 3 analysis parameters. The test-cross parents and the 88 test-cross progeny were genotyped for each marker, genotypes were converted into Joinmap genotype codes, and the segregation data were used to assign loci onto a linkage group with a logarithm of the odds 3 or greater using Joinmap Version 3.0 (Van Ooijen and Voorripps, 2001).

DNA EXTRACTION AND AMPLIFICATION OF WATERMELON RESISTANCE GENE ANALOGS WITH DEGENERATE PRIMERS. 'Calhoun Gray', PI 595203, and PI 296341 were used in this study. 'Calhoun Gray' was shown to be resistant to $F$. oxysporum $\mathrm{f}$. sp. niveum races 0 and 1 (Netzer and Weintall, 1980). PI 296341 has resistance to $F$. oxysporum $\mathrm{f}$. sp. niveum races 0,1 , and 2 (Dane et al., 1998; Martyn and Netzer, 1991). PI 595203 has resistance to the zucchini yellow mosaic virus (Florida and Chinese strains), papaya ringspot virus watermelon strain, cucumber mosaic virus, and watermelon mosaic virus (Guner and Wehner, 2008; Xu et al., 2004). Plants were grown and DNA was extracted from leaf material using the Qiagen DNeasy plant mini kit (Qiagen, Valencia, CA) following the manufacturer's protocols.

WRGA were amplified using previously reported degenerate primers (Table 1). Amplicons were generated in a $25-\mu \mathrm{L}$ reaction volume. Each reaction contained $5 \mu \mathrm{L}$ of Green GoTaq ${ }^{\circledR}$ reaction buffer (Promega), $2.5 \mu \mathrm{L}$ of $25 \mathrm{~mm} \mathrm{MgCl}_{2}$, $2.5 \mu \mathrm{L}$ of $2.5 \mathrm{mM}$ dNTP, $0.25 \mu \mathrm{L}$ of $100 \mu \mathrm{M}$ degenerate primer pair, $0.25 \mu \mathrm{L}$ of GoTaq ${ }^{\circledR}$ DNA polymerase (Promega), 12.25 $\mu \mathrm{L}$ of water, and $2 \mu \mathrm{L}$ of DNA at $10 \mathrm{ng} \cdot \mu \mathrm{L}^{-1}$. Thermocycling conditions were initial melting at $94{ }^{\circ} \mathrm{C}$ for $3 \mathrm{~min}$ followed by

Table 1. Degenerate primers corresponding to conserved domains of resistance genes that were used to amplify watermelon resistance gene analogs.

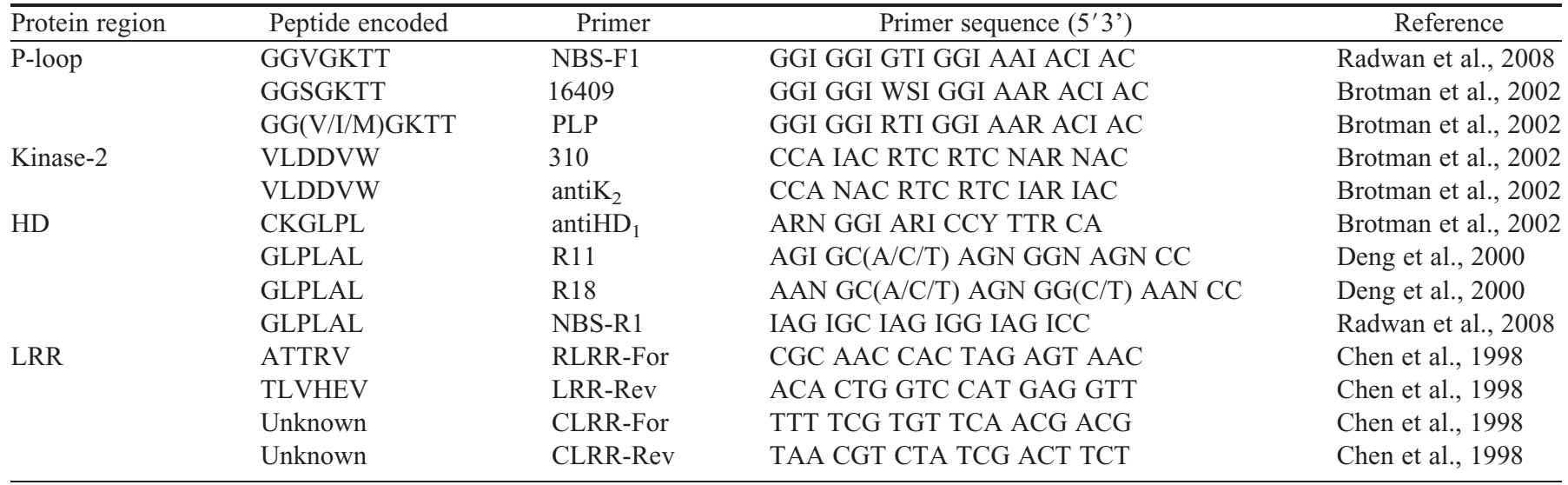


36 cycles of $94^{\circ} \mathrm{C}$ for $30 \mathrm{~s}, 45^{\circ} \mathrm{C}$ for $1 \mathrm{~min}$, and $72^{\circ} \mathrm{C}$ for $1 \mathrm{~min}$ $10 \mathrm{~s}$. A final extension was performed at $72{ }^{\circ} \mathrm{C}$ for $10 \mathrm{~min}$.

Cloning AND SEQuenCING OF WATERMELON RESISTANCE GENE ANALOGS. Amplicons of the correct size $(\approx 500 \mathrm{bp}$ for P-loop to hydrophobic domain products and $\approx 240 \mathrm{bp}$ for P-loop to kinase-2 products) were excised from a 1.5\% agarose gel and gel purified using the Geneclean ${ }^{\circledR}$ Turbo Kit (Qbiogene, Carlsbad, CA). Purified PCR products then were ligated into the pCR2.1-TOPO TA vector (Invitrogen, Carlsbad, CA) using the TOPO TA Cloning Kit (Invitrogen). The ligated products were transformed into TOP10 electrocompetent Escherichia coli cells (Invitrogen). Using a standard blue/ white screen, white colonies were selected and grown overnight in liquid culture under kanamycin selection at 50 $\mu \mathrm{g} \cdot \mathrm{mL}^{-1}$. Plasmid DNA was isolated using a Qiaprep Mini Spin Kit (Qiagen). These plasmids were sequenced using the GenomeLab Dye Terminator Cycle Sequencing kit (Beckman Coulter) as suggested by the manufacturer except half reactions were used. The sequencing reaction was resolved using a Beckman CEQ 8800 Genetic Analysis System (Beckman Coulter).

Sequence analysis. Sequences from clones were screened for vector contamination using the program VecScreen (National Center for Biotechnology Information, 2009) and were aligned using Sequencher (GeneCodes, Ann Arbor, MI). Sequence homology queries were submitted to GenBank using the BLASTn and BLASTx (Altschul et al., 1997) algorithm from the National Center for Biotechnology Information. Those sequences with similarity to resistance genes were assembled into contigs. A representative from each contig was translated using ExPASy (Gasteiger et al., 2003) and these amino acid sequences were aligned using AliBee (Brodsky et al., 1992). The amino acid alignment was in the CLUSTAL W (1.60) format. A distance matrix was created using Geneious Pro Version 4.6 by performing a global alignment with free end gaps and using the cost matrix Blosum62 (Drummond et al., 2009). Dendrograms were created in AliBee using the "phylogram" picture format and bootstrapping 100 times. Sequences from known disease resistance genes for flax (Linum usitatissimum) L6 (U27081) and $M$ (U73916); rice (Oryza sativa) Pib (AB013449) and XA1 (AB002266.1); Arabidopsis thaliana RPS2 (U12860), RPM1 (NM_111584), RPP13 (AF2097311), RFL1 (AF074916), and RPP8 (AF089710); and tobacco (Nicotiana glutinosa) $N$ (U15605) tomato (Solanum lycopersicum) PRF (U65391), I2C-1 (AAB63274), and RPP8 (AF089710) were obtained from GenBank. These sequences were trimmed to include only the P-loop to the kinase-2, or P-loop to the hydrophobic domain.

MARKer DeVELOPMENT. To develop markers for mapping as well as to examine the conservation of these markers among the genera of the Cucurbitaceae, sequence-tagged site (STS) primers were developed from a clone representing each WRGA class. Nucleotide sequences of all WRGA groups were aligned using AliBee and WRGA-STS primers were designed to avoid degenerate primer sites and conserved motifs, thus selecting for each WRGA class. PCR conditions for amplification of these markers was the same as the WMU primers listed previously except primers were not multiplexed.

Digestions of the STS PCR products with AluI, MseI, HaeIII, DraI, SacI, and $T a q^{\alpha} \mathrm{I}$ were performed as suggested by the manufacturer (New England Biolabs, Ipswich, MA) using the appropriate buffers and bovine serum albumin.
For single nucleotide polymorphism (SNP) detection, specific primers were developed [Supplemental Table 2 (available online with the electronic version of this article), primers named WRGA large amplicon-WRGAL] to generate the largest amplicon for each WRGA (WRGA1, 7, 15, 82, 83, $102,110,113$, and 147) but avoiding conserved motifs. Amplicons were generated from each of the test-cross parents for each primer set as follows: each reaction contained $4 \mu \mathrm{L}$ of Green GoTaq ${ }^{\circledR}$ reaction buffer (Promega), $1 \mu \mathrm{L}$ of $10 \mathrm{~mm}$ $\mathrm{dNTP}, 1 \mu \mathrm{L}$ each of $5 \mu \mathrm{M}$ forward and reverse primer, $0.1 \mu \mathrm{L}$ of GoTaq ${ }^{\circledR}$ DNA polymerase (Promega), $12.9 \mu \mathrm{L}$ of water, and $1 \mu \mathrm{L}$ of DNA at $10 \mathrm{ng} \cdot \mu \mathrm{L}^{-1}$. Thermocycling conditions began with $94{ }^{\circ} \mathrm{C}$ for $2 \mathrm{~min}$ followed by 40 cycles of $94{ }^{\circ} \mathrm{C}$ for $30 \mathrm{~s}$, $55^{\circ} \mathrm{C}$ for $30 \mathrm{~s}$, and $72{ }^{\circ} \mathrm{C}$ for $1 \mathrm{~min}$, and a final extension of $72{ }^{\circ} \mathrm{C}$ for $10 \mathrm{~min}$. The amplified fragments were excised from an agarose gel, purified, and ligated into the pCR2.1-TOPO TA vector (Invitrogen) using the TOPO TA Cloning Kit (Invitrogen), transformed into Top10 E. coli (Invitrogen), and plasmid DNA was isolated as described previously. Both forward and reverse strand sequencing was performed at the U.S. Department of Agriculture (USDA), Agricultural Research Service (ARS), Fort Pierce, FL, location using the BigDye ${ }^{\circledR}$ Terminator Cycle Sequencing Kit Version 3.1 (Applied Biosystems, Foster City, CA) sequencing chemistry and run on the ABI 3730XL DNA Analyzer (Applied Biosystems). Sequences for each test-cross parent/primer combination were assembled and aligned as described previously, polymorphisms were identified, and endonucleases were chosen that would generate a polymorphism based on a SNP at the restriction site using NEBcutter (Vincze et al., 2003). WRGA1 (GU124547-GU124549), WRGA7 (GU124550-GU124552), WRGA102 (GU124553-GU124555), WRGA110 (GU124556-GU124558), WRGA113 (GU124559GU124561), and WRGA147 (GU124562-GU124564) sequences were deposited into GenBank.

A primer pair, WRGA1SNP-F and WRGA1SNP-R (Supplemental Table 2), was designed around a SNP specific to 'NHM' but not found in Griffin 14113 or PI 386015. This primer pair was used to generate a single amplicon in 'NHM' and no amplification product in the other testcross parents. Amplifications of the test-cross parent DNA and the test-cross mapping population were performed on a Stratagene Mx3000P QPCR System (Stratagene, La Jolla, CA) and Brilliant ${ }^{\circledR}$ SYBR ${ }^{R}$ Green QPCR Master Mix Kit (Stratagene). Each reaction contained $12.5 \mu \mathrm{L}$ of $2 \times$ Brilliant ${ }^{\circledR}$ SYBR $\AA$ Green QPCR Master Mix, $5 \mu \mathrm{L} 1.5 \mu \mathrm{M}$ WRGA1SNP-F and WRGA1SNP-R primer mix, $0.375 \mu \mathrm{L}$ of $1 \mathrm{~mm}$ reference dye (Stratagene), $4.25 \mu \mathrm{L}$ of water, and $3 \mu \mathrm{L}$ of DNA at $5 \mathrm{ng} \cdot \mu^{-1}$. Thermocycling conditions were $95{ }^{\circ} \mathrm{C}$ for $10 \mathrm{~min}$ followed by 40 cycles of $95^{\circ} \mathrm{C}$ for $30 \mathrm{~s}, 57^{\circ} \mathrm{C}$ for $1 \mathrm{~min}$, and $72^{\circ} \mathrm{C}$ for $30 \mathrm{~s}$. $\mathrm{A} \mathrm{Ct}$ value of 31 or fewer cycles was scored as positive for amplification and a $\mathrm{Ct}$ value of 34 or more cycles was scored as negative for amplification.

AMPLIFICATION OF WATERMELON RESISTANCE GENE ANALOGSEQUENCE-TAGgED SITE MARKERS FROM CUCURBITS. WRGA-STS primers were used to amplify DNA from Praecitrullus fistulosus, Citrullus spp., Lagenaria siceraria, Cucurbita pepo, and Cucumis spp. using seeds obtained from the USDA, ARS, Plant Genetic Resources and Conservation Unit in Griffin, GA. Seeds from PIs classified as Cucumis spp. and C. pepo were obtained from USDA, ARS, North Central Regional PI Station in Ames, IA. PI accessions 220778, PI 386016, PI 386018, PI 386024, PI 386025, PI 386026, and PI 432337 were used to represent 
C. colocynthis. PI 189225, PI 244018, PI 244019, PI 248774 , PI271779, PI 299378, and PI 299379 were used to represent $C$. lanatus var. citroides. PI 169290, PI 203551, PI 248178, PI 270306, and PI 595203 were used to represent C. lanatus var. lanatus. 'Crimson Sweet', 'Charleston Gray', 'Picnic', 'All Sweet', 'Jubilee', 'New Hampshire Midget', 'Sugar Baby', and 'Micky Lee' were used to represent the cultivars of var. lanatus; 'Ananas Yokneum' and MR1 were used to represent Cucumis melo. African horned cucumber was used to represent Cucumis metuliferus. 'Early Prolific Straightneck' was used to represent C. реро. PI 270456, PI 271357, PI 271354, PI 273662, PI 273663, PI 280632, PI 280636, and PI358056 were used to represent L. siceraria. PI 381747 and PI 381745 were used to represent P. fistulosus.

\section{Results}

IDENTIFICATION OF WATERMELON EXPRESSED SEQUENCE TAGS WITH HOMOLOGY TO DISEASE RESISTANCE GENES OR RESISTANCE GENE ANALOGS. Twenty-seven watermelon diseaseresistant EST homologs were identified in the International Cucurbit Genomics Initiative database (International Cucurbit Genomics Initiative, 2009). Five of these ESTs were polymorphic between the testcross parents and three of the five, WMU2175, WMU1502, and WMU2837, could be placed onto the previously constructed watermelon map (Fig. 1) (Levi et al., 2006). WMU2175 and WMU1502 had homology (e-value of $3 \times 10^{-12}$ and $3 \times 10^{-45}$, respectively) to a pathogenesis-related transcription factor and ethylene-responsive factor homologs in Medicago truncatula (ABD28728 and ABE80929, respectively) and map to watermelon linkage Groups I and III, respectively. WMU2837 had homology (e-value of $8 \times 10^{-7}$ ) to the Mlo-related protein in M. truncatula (ABE92274) and mapped to linkage group VII (Fig. 1).

Cloning AND SEQuence anAlysis OF WATERMELON RESISTANCE GENE Analogs. Primers previously designed to amplify domains of resistance genes from a wide range of plant species (Table 1) were used to amplify WRGA. Of the primers tested, only those primer pairs listed in Table 2 amplified sequences from watermelon with homology to resistance genes or resistance gene analogs. One hundred thirty-two clones were sequenced, of which 66 contained inserts that encoded homologs of retrotransposons, ATP
XIII

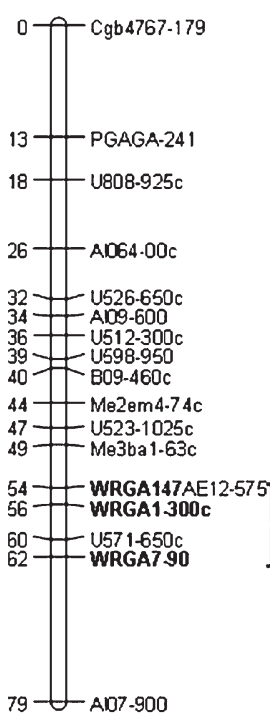
of the odds (LOD) 3.0 or greater. groups. ${ }^{z}$ synthases, ATP-binding cassette transporter, peptidases, nucleases, cytochrome c oxidases, nodulins, or lacked database homologies. Another 66 clones contained inserts with homology to NBS-LRR resistance genes from other species. These latter 66 clones were assembled into eight WRGA groups (Table 2)

The deduced amino-acid sequences of the eight WRGA groups were aligned. The conserved motifs of the NBS as well as conserved motifs of unknown function (Meyers et al., 1999) could be identified from all WRGA groups [Fig. 2, pink shaded amino acids (see the online version of this article to view colors)]. Five WRGA groups span the P-loop to the hydrophobic
III

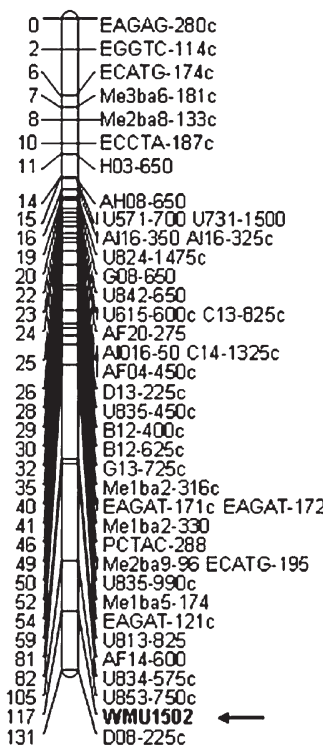

I

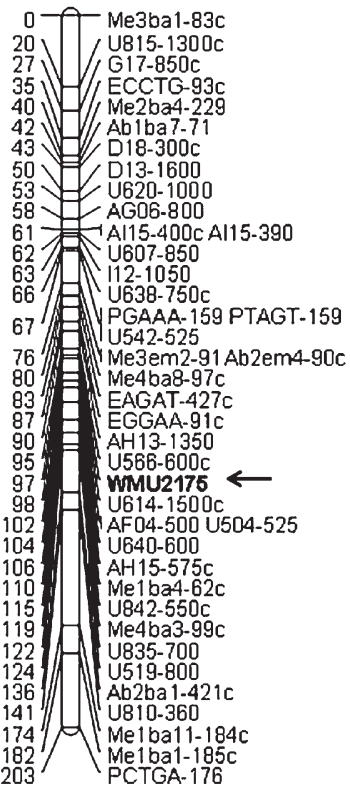

VII

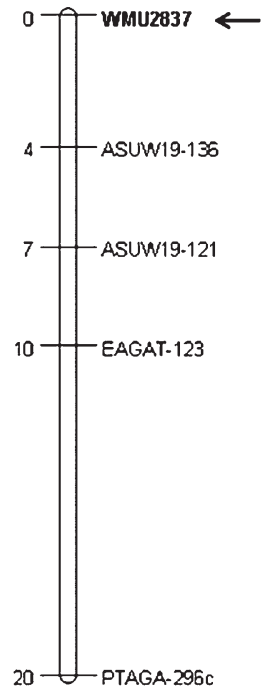

Fig. 1. Map positions of three disease resistance expressed sequence tag (EST) homologs and three watermelon nucleotide binding site-leucine-rich repeat (NBS-LRR) resistance gene analogs. Marker name is followed by the size of the fragment (in base pairs) and presence of a "c" after the size indicates the allele came from the testcross parent cultivar New Hampshire Midget. Absence of a " $c$ " indicates that the allele is derived from the testcross parent Griffin 14113. Watermelon unigene markers (WMU)2175, WMU1502, and WMU2837 and watermelon resistance gene analog (WRGA)147 were codominant. EST marker WMU2175 amplified a product 303 and 320 bp, EST marker WMU1502 amplified a product at 232 and 235 bp, EST marker WMU2837 amplified a product at 261 and $257 \mathrm{bp}$, and WRGA147 amplified a product at 450 and 350 bp in Griffin 14113 and 'New Hampshire Midget', respectively. WRGA7 and WRGA147 were cleaved amplified polymorphic sequence (CAPS) markers cleaved with the enzyme MseI and BsaI, respectively, and WRGA1 was a presence/ absence single nucleotide polymorphism marker. All markers were assigned to linkage groups with a logarithm

Table 2. Eight watermelon resistance gene analogs (WRGA) groups, the number of sequences in each group, degenerate primer used, genotype used, and the size of each amplicon for the WRGA

\begin{tabular}{lcllc}
\hline WRGA/accession & Sequences (no.) & \multicolumn{1}{c}{ Primers } & \multicolumn{1}{c}{ Genotype } & Size (bp) \\
\hline 1/GU124539 & 45 & NBS-F1, NBS-R1 & PI 595203 & 512 \\
7/GU124546 & 2 & NBS-F1, NBS-R1 & PI 296341 & 507 \\
$82 /$ GU124542 & 11 & 16409,310 & Calhoun Gray & 243 \\
$83 /$ GU124543 & 3 & 16409,310 & Calhoun Gray & 243 \\
102/GU124540 & 2 & PLP, antiK & PI 296341 & 246 \\
110/GU124544 & 2 & PLP, antiHD & PI 595203 & 506 \\
$113 /$ GU124545 & 1 & PLP, antiHD & Calhoun Gray & 506 \\
147/GU124541 & 1 & NBS-F1, R11 & PI 595203 & 515 \\
\hline
\end{tabular}

${ }^{\mathrm{z}}$ Accession numbers are found in GenBank. 
domain $(\approx 500 \mathrm{bp})$, whereas three groups span the P-loop to the kinase-2 domain ( $\approx 240 \mathrm{bp}$ ) (Fig. 2, underlined amino acids represent degenerate primer sites). The motifs of the NBS, including the P-loop (which served as a degenerate primer site), kinase-2, and kinase-3a (De Young and Innes, 2006), were identified in the WRGA groups. A consensus watermelon amino acid sequence for the kinase-2 motif for the TIR-NBSLRR WRGA is $\mathrm{L}(\mathrm{V} / \mathrm{I})(\mathrm{V} / \mathrm{I}) \mathrm{LD}(\mathrm{V} / \mathrm{M})(\mathrm{N} / \mathrm{D})$ and the consensus amino acid sequence for the kinase-3a domain for WRGA is FGXGS. Also, conserved motifs of unknown function, RNBSA, RNBS-C, and the hydrophobic domain, were identified within each WRGA group. Two types of RNBS-A motifs (RNBS-A-nonTIR and RNBS-A-TIR) were identified in the WRGA groups. RNBS-A-TIR occurred in the NBS region of the R-genes that contained the TIR domain. RNBS-A-nonTIR occurred in the NBS region of the R-genes without a TIR domain. A watermelon consensus RNBS-A-non-TIR motif was identified, F (D/H)(K/E)(T/I) I W C V (S/T)(A/K/E)(P/T)F. WRGA1, WRGA7, WRGA110, WRGA113, and WRGA147 had a RNBS-A-TIR motif, whereas WRGA82, WRGA83, and WRGA102 had a RNBS-A-non-TIR motif. Furthermore, if the last residue of the kinase-2 motif was a tryptophan residue (W) or an aspartic acid (D), a NBS region was classified with more than $95 \%$ accuracy as a non-TIR-NBS or TIR-NBS, respectively (Meyers et al., 1999). WRGA1, WRGA7, WRGA110, WRGA113, and WRGA147, which possessed a RNBS-A-TIR motif, had an aspartic acid (D) or asparagine (N) at the last residue of the kinase- 2 motif. Thus, those WRGA clones likely possessed a TIR domain, whereas WRGA clones 82, 83, and 102 did not. This is also indicated in the dendrograms generated in AliBee (Fig. 3, P-loop to the hydrophobic domain; and Fig. 4, P-loop to kinase-2 domain), where the TIR and non-TIR-deduced amino acid sequences separated into two distinct groups. WRGA1, WRGA7, WRGA 110 , WRGA 113 , and WRGA147 were located within the TIR-NBS group, which included the TIR-NBS-LRR resistance genes $L 6$ and $M$ from flax and $N$ from tobacco (Figs. 3 and 4). In contrast, WRGA82, WRGA83, and WRGA102 were located within the non-TIR-NBS group, which included non-TIR-NBS-LRR resistance genes $X A 1$ from rice and $P R F$ from tomato (Fig. 3). Thus, the degenerate primer pairs NBSF1- R1, NBSF1-R11, and PLP-antiHD1 amplified WRGA that likely possess a TIR domain, whereas the degenerate primers 16409-310 and PLP-antiK2 amplified WRGA that likely are without a TIR domain (Table 2; Fig. 2).

From the alignment of amino acids from the eight WRGA, a distance matrix was created (data not shown) displaying the number of substitutions per site between WRGA. For the WRGA, the distance matrix range was from 0.339 for WRGA113 and WRGA110 to 1.803 for the comparison of WRGA82 and WRGA7. The distance matrix from the alignment of the known resistance genes and the WRGA ranged from 0.215 for $L 6$ and $M$ to 3.027 for many WRGA compared with known resistance genes.

Comparisons of the eight WRGA with GenBank entries using BLASTx revealed significant similarities between the WRGA and resistance gene analogs from cucumber (Cucumis sativus), melon (C. melo), and crookneck pumpkin (Cucurbita moschata) with $66 \%$ to $92 \%$ amino acid identity (Table 3 ). WRGA102 had 100\% amino acid identity to a watermelon resistance gene analog, AAZ82762. WRGA7 was most similar to a 469-bp region on melon BAC 31016 (AY582736) with a nucleotide identity of $88 \%$ and an e-value of $8 \times 10^{-156}$ when BLASTn is used. This BAC contains a cluster of eight TIRNBS-LRR RGAs and has been mapped to melon linkage Group 7 in a region where the melon disease resistance genes Fom-1 and Prv are located as well as a QTL for resistance against cucumber mosaic virus (Van Leeuwen et al., 2005). WRGA110 is most similar to melon resistance gene analog MRGH-18 (AJ251869) at an e-value of $5 \times 10^{-148}$ and a nucleotide identity of $85 \%$ when BLASTn is used. MRGH-18 maps to melon linkage Group 8 (Van Leeuwen et al., 2005).

DEVELOPMENT OF WATERMELON RESISTANCE GENE ANALOGSEQUENCE-TAGGED SITE MARKERS. For each WRGA group, WRGA-STS markers were designed (Supplemental Table 1) and used to amplify products from the test-cross parents, Griffin14113, 'New Hampshire Midget', and PI 386015. Digests of the WRGA-STS PCR products with six endonucleases 


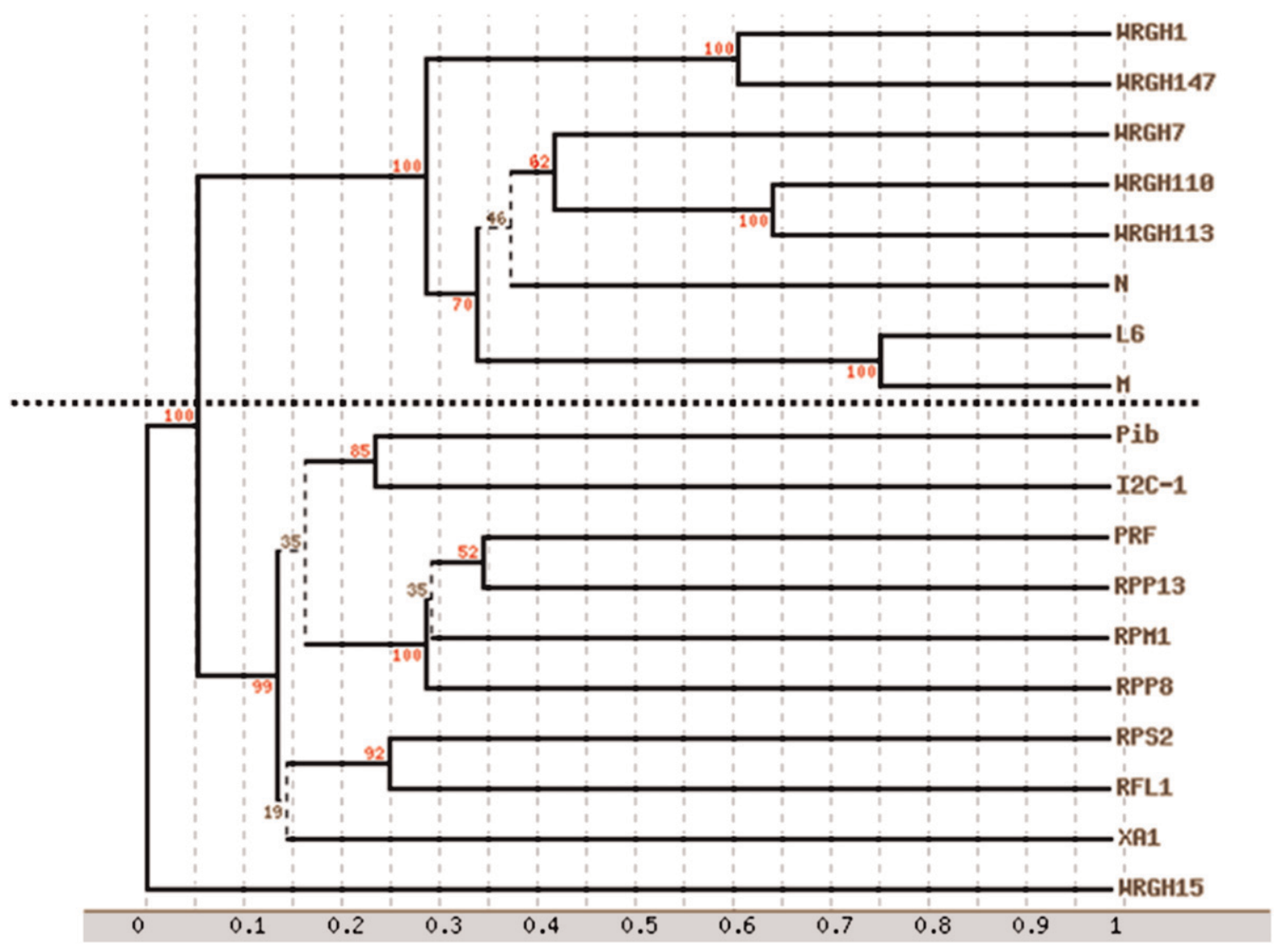

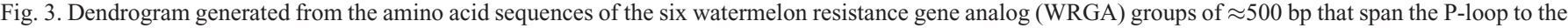
hydrophobic domain with known nucleotide binding site-leucine-rich repeat (NBS-LRR) disease resistance genes. Sequences above the dashed line are Drosophila Toll and mammalian interleukin-1 receptor (TIR)-NBS, whereas sequences below the line are non-TIR-NBS with the exception of WRGA15, which served as an unrelated sequence with no blast analogy. The scale at the bottom of the figure represents amino acid similarity.

generated only one polymorphic marker, that being the WRGA7 cleaved amplified polymorphic sequence (CAPS) marker in combination with the enzyme MseI.

WRGA1, WRGA102, WRGA110, WRGA113, and WRGA147 were sequenced from Griffin14113, 'NHM', and PI 386015 to identify possible SNPs for placement on the watermelon test-cross map. SNPs were identified only in WRGA1, WRGA113, and WRGA147. Based on these SNPs, CAPS markers were developed for WRGA113 (using the enzyme HhaI) and WRGA147 (enzyme BsaI) (Supplemental Table 2). No suitable restriction sites were found in WRGA1, but primers were designed to generate a presence/absence PCRbased polymorphism (Supplemental Table 2). The WRGA113 CAPS marker exhibited segregation distortion in the watermelon test-cross population and could not be mapped. WRGA147CAPS, WRGA1SNP, and WRGA7CAPS markers were placed at 54, 56, and $62 \mathrm{cM}$, respectively, on linkage Group XIII (Fig. 1) on the watermelon test-cross map (Levi et al., 2006).

Watermelon RESistance GENE ANALOGS ARE CONSERVED Within THE GENERa OF CuCurbitaceae. The STS primers were used to amplify DNA from P. fistulosus, Citrullus spp., $L$. siceraria, and Cucumis spp. and C. pepo accessions. Amplicons of the approximate expected size were amplified in all genera for WRGA-STS 1, 7, 82, 83, and 110. No PCR product of the expected size was generated in accessions of C. melo or C. pepo for WRGA-STS 102, 113, or 147. WRGA-STS 102 and WRGA-STS 113 primers failed to amplify in P. fistulosus or C. metuliferus accessions, whereas WRGA-STS 113 failed to amplify in L. siceraria accessions.

\section{Discussion}

In this study, eight groups of NBS-LRR resistance gene analogs were isolated from watermelon in an effort to characterize the types of WRGA and to identify linkage groups where these NBS-LRR resistance gene analogs reside. Similar to findings in other dicots where both TIR and non-TIR-NBSLRR groups were found (Meyers et al., 1999), five TIR-NBSLRR and three non-TIR-NBS-LRR groups were isolated (Fig. 3). Furthermore, known resistance genes clustered into TIR and non-TIR groups in our study, which is in agreement with previous reports (Meyers et al., 1999). WRGA110 and WRGA113 clustered on the dendrogram with the flax resistance genes $L 6$ and $M$, which encode rust resistance proteins (Fig. 3).

Three watermelon EST disease resistance homologs as well as three WRGA were placed on a previously constructed testcross map (Levi et al., 2006). The ESTs mapped to different linkage groups (Fig. 1), and no markers mapped near the marker linked to the $F$. oxysporum race 1 resistance gene on linkage Group IV (marker P01-700, Levi et al., 2002) or the markers 


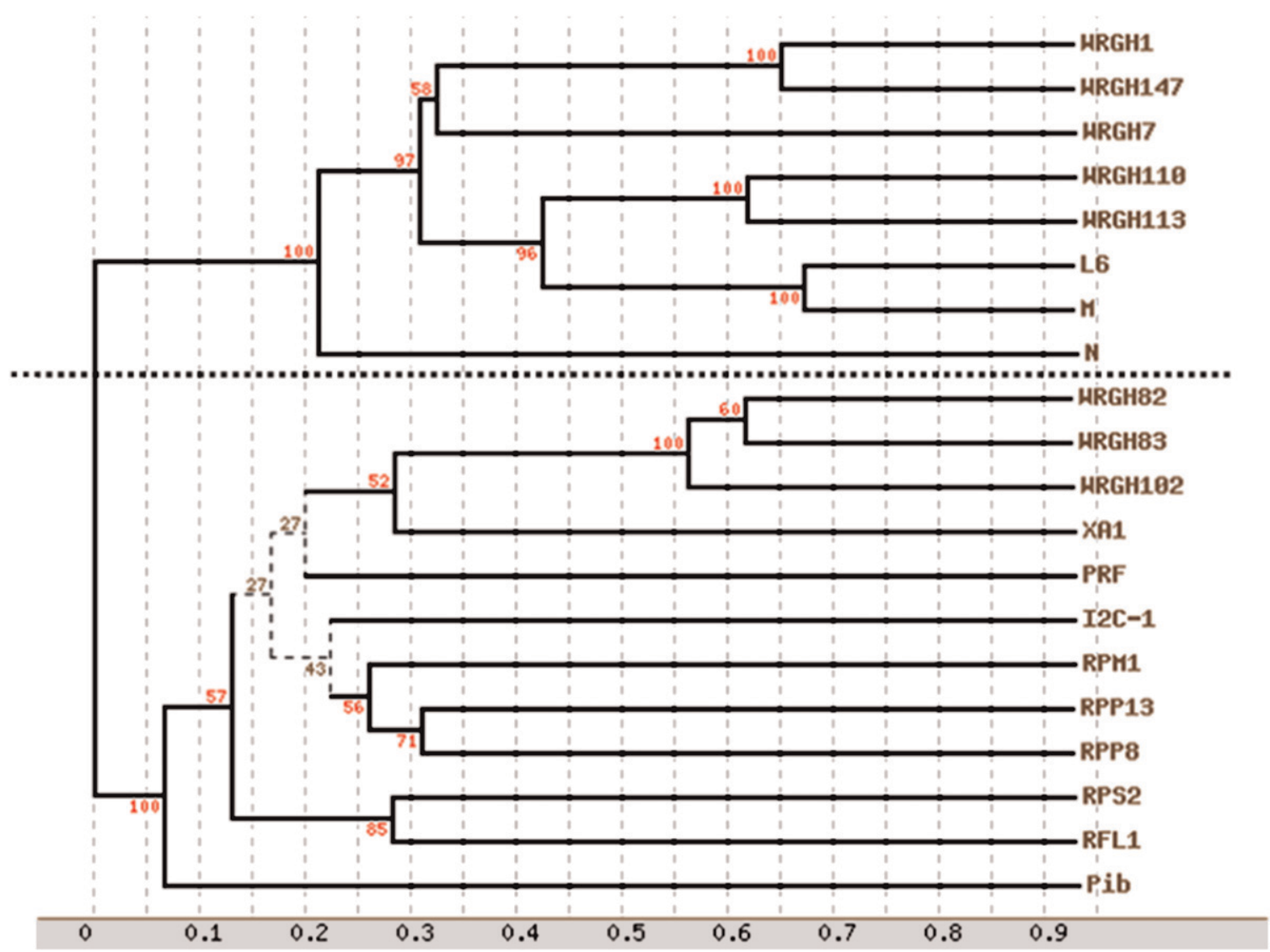

Fig. 4. Dendrogram generated from amino acid sequences that span the P-loop to the kinase-2 domain for eight watermelon resistance gene analogs (WRGA) and known nucleotide binding site-leucine-rich repeat (NBS-LRR) resistance genes. Sequences above the dashed line are Drosophila Toll and mammalian interleukin-1 receptor- nucleotide binding site (TIR-NBS), whereas sequences below the line are non-TIR-NBS.

Table 3. Similarity of watermelon resistance gene analogs (WRGA) to accessions within GenBank using BLASTX.

\begin{tabular}{llcc}
\hline WRGA group & \multicolumn{1}{c}{ Blastx top hit, organism (GenBank accession no.) } & Amino acid identity (\%) & E-value \\
\hline WRGA1 & NBS-p108-7, Cucumis sativus (AAV38977) & 80 & 46 \\
WRGA7 & NBS resistance protein, Cucurbita moschata (ABM89098) & 92 \\
WRGA82 & NBS-p14-35, C. sativus (AAV38980) & 91 \\
WRGA83 & NBS-p14-24, C. sativus (AAV38978) & $7 \mathrm{e}^{-36}$ \\
WRGA102 & NBS-ARC-175s7n, Citrullus lanatus (AAZ82762) & $3 \mathrm{e}^{-37}$ \\
WRGA110 & Resistance gene analog, Cucumis melo (CAB88868) & 700 \\
WRGA113 & Resistance protein-like, C. melo (ABR67409) & 69 \\
WRGA147 & NBS-p108-7, C. sativus (AAV38977) & 66 & $3 \mathrm{e}^{-63}$ \\
\hline
\end{tabular}

linked to the zucchini yellow mosaic resistance gene on linkage group XIV [CAPS1, CAPS2, ZYRP (Harris et al., 2009; Ling et al., 2009)]. In contrast, WRGA1SNP, WRGA7CAPS, and WRGA147CAPS markers mapped to an $8 \mathrm{cM}$ region on linkage Group XIII (Fig. 1). Because WRGA1, WRGA7, and WRGA147 are different TIR-NBS-LRR resistance gene analogs and map to the same region on linkage Group XIII, it is likely that a cluster of resistance genes exists in this linkage region. This linkage group requires further investigation because it may possess additional putative resistance gene analogs.

Although the placement of morphological markers onto the watermelon test-cross map is still in its infancy, the use of genetic resources from melon has enabled advances in watermelon. For example, we used degenerate primers designed for melon to capture eIF4E in watermelon and found this gene to be linked to the resistance gene for ZYMV-FL (Ling et al., 2009). In this study, WRGA7 is most similar to a region on melon BAC 31016 that contains eight TIR-NBS-LRR R gene analogs and is located near the melon Fom-1, papaya ringspot virus, and cucumber mosaic virus resistance genes. Because WRGA7CAPS maps to the watermelon linkage Group XIII, WRGA7CAPS or markers nearby (WRGA1SNP, WRGA147CAPS) may be linked to fusarium wilt, papaya ringspot virus, or cucumber mosaic virus resistance genes in watermelon.

The eight groups of WRGA isolated not only tag resistance gene analogs in watermelon, but also amplify in other genera of the family Cucurbitaceae. WRGA1, WRGA7, WRGA82, WRGA83, and WRGA110 amplified in all genera tested. This 
may suggest these resistance gene analogs are derived from an ancient progenitor. In contrast, WRGA102, WRGA113, and WRGA147 amplified only in genera that were most closely related to Citrullus and these resistance gene analogs may have evolved after speciation.

We described the first study of the isolation and characterization of resistance gene analogs from watermelon. The development of markers where resistance gene analogs reside may identify resistance genes against diseases of interest. These identified markers linked to resistance genes can then be used for marker-assisted selection.

\section{Literature Cited}

Altschul, S.F., T. Madden, A. Schaffer, J. Zhang, Z. Zhang, W. Miller, and D.J. Lipman. 1997. Gapped BLAST and PSI-BLAST: A new generation of protein database search programs. Nucleic Acids Res. 25:3389-3402.

Brodsky, L.I., A.V. Vasiliev, Y.L. Kalaidzidis, Y.S. Osipov, R.L. Tatuzov, and S.I. Feranchuk. 1992. GeneBee: The program package for biopolymer structure analysis. Dimacs 8:127-139.

Brotman, Y., L. Silberstein, I. Kovalski, C. Perin, C. Dogimont, M. Pitrat, J. Klingler, G.A. Thompson, and R. Perl-Treves. 2002. Resistance gene analogues in melon are linked to genetic loci conferring disease and pest resistance. Theor. Appl. Genet. 104: 1055-1063.

Chen, X.M., R.F. Line, and H. Leung. 1998. Genome scanning for resistance-gene analogs in rice, barley, and wheat. Theor. Appl. Genet. 97:345-355.

Collier, S.M. and P. Moffett. 2009. NB-LRRs work a 'bait and switch' on pathogens. Trends Plant Sci. 14:521-529.

Cordero, J.C. and D.Z. Skinner. 2002. Isolation from alfalfa of resistance gene analogues containing nucleotide binding sites. Theor. Appl. Genet. 104:1283-1289.

Dane, F., L.K. Hawkins, and J.D. Norton. 1998. New resistance to race 2 of Fusarium oxysporum f. sp. niveum in watermelon. Cucurbit Genet. Coop. Rpt. 21:37-39.

Deng, Z., S. Huang, P. Ling, C. Chen, C. Yu, C.A. Weber, G.A. Moore, and F.G. Gmitter. 2000. Cloning and characterization of NBS-LRR class resistance-gene candidate sequences in citrus. Theor. Appl. Genet. 101:814-822.

Deslandes, L., J. Olivier, N. Peeters, D.X. Fena, M. Khounlotham, C. Boucher, I. Somssich, S. Genin, and Y. Marco. 2003. Physical interaction between RRsI-R, a protein conferring resistance to bacterial wilt, and PopP2, a class III effector targeted to the plant nucleus. Proc. Natl. Acad. Sci. USA 100:8024-8029.

DeYoung, B.J. and R.W. Innes. 2006. Plant NBS-LRR proteins in pathogen sensing and host defense. Nat. Immunol. 7:1243-1249.

Drummond, A.J., B. Ashton, M. Cheung, J. Heled, M. Kearse, R. Moir, S. Stones-Havas, T. Thierer, and A. Wilson. 2009. Geneious v4.5, 2009. 8 Sept. 2009. <http://www.geneious.com/default,28,downloads. sm;jsessionid=1B431D3734ABFCDC4ED03775B7CE88F5>.

Gasteiger, E., A. Gattiker, C. Hoogland, I. Ivanyi, R.D. Appel, and A. Bairoch. 2003. ExPASy: The proteomics server for in-depth protein knowledge and analysis. Nucleic Acids Res. 31:3784-3788.

Gowda, B.S., J.L. Miller, S.S. Rubin, D.R. Sharma, and M.P. Timko. 2002. Isolation, sequence analysis, and linkage mapping of resistance-gene analogs in cowpea (Vigna unguiculata L. Walp.). Euphytica 126:365-377.

Guner, N. and T.C. Wehner. 2008. Overview of potyvirus resistance in watermelon, p. 451-451. In: M. Pitrat (ed.). Cucurbitaceae 2008. Proc. IXth EUCARPIA meeting on genetics and breeding of Cucurbitaceae, L'Institut National de la Recherche Agronomique, Avignon, France, 21-24 May 2008.

Harris, K.R., K. Ling, W.P. Wechter, and A. Levi. 2009. Identification and utility of markers linked to the zucchini yellow mosaic virus resistance gene in watermelon. J. Amer. Soc. Hort. Sci. 134:1-6.
Hopkins, D.L., C.M. Thompson, J. Hilgren, and B. Lovic. 2003. Wet seed treatment with peroxyacetic acid for the control of bacterial fruit blotch and other seedborne diseases of watermelon. Plant Dis. 87:1495-1499.

International Cucurbit Genomics Initiative. 2009. Watermelon EST collection. 4 Aug. 2009. <http://www.icugi.org/cgi-bin/ICuGI/EST/ home.cgi?organism=watermelon $>$.

Jia, Y., S.A. McAdams, G.T. Bryan, H.P. Hershey, and B. Valent. 2000. Direct interaction of resistance gene and avirulence gene products confers rice blast resistance. EMBO J. 19:4004-4014.

Levi, A., A. Davis, A. Hernandez, P. Wechter, J. Thimmapuram, T. Trebitsh, Y. Tadmor, N. Katzir, V. Portnoy, and S. King. 2006. Genes expressed during the development and ripening of watermelon fruit. Plant Cell Rep. 25:1233-1245.

Levi, A., C.E. Thomas, T. Joobeur, X. Zhang, and A. Davis. 2002. A genetic linkage map for watermelon derived from a trestcross population: (Citrullus lanatus var. citroides $\times$ C. lanatus var. lanatus $) \times$ Citrullus colocynthis. Theor. Appl. Genet. 105:555-563.

Levi, A., C.E. Thomas, T.C. Wehner, and X. Zhang. 2001. Low genetic diversity indicates the need to broaden the genetic base of cultivated watermelon. HortScience 36:1096-1101.

Ling, K.S., K.R. Harris, J.D.F. Meyer, A. Levi, N. Guner, T.C. Wehner, A. Bendahmane, and M.J. Havey. 2009. Non-synonymous single nucleotide polymorphisms in the watermelon eIF4E gene are closely associated with resistance to zucchini yellow mosaic virus. Theor. Appl. Genet. 120:191-200.

Lopez, R., A. Levi, B. Shepard, A.M. Simmons, and D.M. Jackson. 2005. Sources of resistance to two-spotted spider mite (Acari: Tetranychidae) in Citrullus spp. HortScience 40:1661-1663.

Martyn, R.D. and D. Netzer. 1991. Resistance to races 0, 1, and 2 of fusarium wilt of watermelon in Citrullus sp. PI 296341-FR. HortScience 26:429-432.

McHale, L., X. Tan, P. Koehl, and R.W. Michelmore. 2006. Plant NBS-LRR proteins: Adaptable guards. Genome Biol. 7:212.

Meyers, B.C., A.W. Dickerman, R.W. Michelmore, S. Sivaramakrishnan, B.W. Sobral, and N.D. Young. 1999. Plant disease resistance genes encode members of an ancient and diverse protein family within the nucleotide-binding superfamily. Plant J. 20:317-332.

Nair, R.A. and G. Thomas. 2007. Evaluation of resistance gene (Rgene) specific primer sets and characterization of resistance gene candidates in ginger (Zingiber officinale Rosc.). Curr. Sci. 93:61-66. National Center for Biotechnology Information. 2009. VecScreen. 12 Aug. 2009. <http://www.ncbi.nlm.nih.gov/VecScreen/VecScreen. html>.

Netzer, D. and C. Weintall. 1980. Inheritance of resistance in watermelon to race 1 of Fusarium oxysporum f. sp. niveum. Plant Dis. 64:853854.

Radwan, O., S. Gandhi, A. Heesacker, B. Whitaker, C. Taylor, A. Plocik, R. Kesseli, A. Kozik, R.W. Michelmore, and S.J. Knapp. 2008. Genetic diversity and genomic distribution of analogs encoding NBS-LRR disease resistance proteins in sunflower. Mol. Genet. Genomics 280:111-125.

Simmons, A.M. and A. Levi. 2002. Sources of whitefly (Homoptera: Aleyrodidae) resistance in Citrullus for the improvement of cultivated watermelon. HortScience 37:581-584.

Strange, E.B., N. Guner, Z. Pesic-VanEsbroeck, and T.C. Wehner. 2002. Screening the watermelon germplasm collection for resistance to papaya ringspot virus type-W. Crop Sci. 42:1324-1330.

Thies, J.A. and A. Levi. 2007. Characterization of watermelon (Citrullus lanatus var. citroides) germplasm for resistance to rootknot nematodes. J. Nematol. 42:1530-1533.

Van der Biezen, E.A. and J.D.G. Jones. 1998. Plant disease-resistance proteins and the gene-for-gene concept. Trends Biochem. Sci. 23: 454-456.

Van Leeuwen, H., J. Garcia-Mas, M. Coca, P. Puigdomenech, and A. Monfort. 2005. Analysis of the melon genome in regions encompassing TIR-NBS-LRR resistance genes. Mol. Genet. Genomics 273:240-251. 
Van Ooijen, J.W. and R.E. Voorrips. 2001. JoinMap ${ }^{\circledR}$ 3.0, software for the calculation of genetic linkage maps. Plant Research International, Wageningen, The Netherlands.

Vincze, T., J. Posfai, and R.J. Roberts. 2003. NEBcutter: A program to cleave DNA with restriction enzymes. Nucleic Acids Res. 31:3688-3691. Wehner, T.C. 2008. Overview of the genes of watermelon, p. 79-90. In: M. Pitrat (ed.). Cucurbitaceae 2008. Proc. IXth EUCARPA meeting on genetics and breeding of Cucurbitaceae, L'institut National de la Recherche Agronomique, Avignon, France, 21-24 May 2008.
Xu, Y., D. Kang, Z. Shi, H. Shen, and T. Wehner. 2004. Inheritance of resistance to zucchini yellow mosaic virus and watermelon mosaic virus in watermelon. J. Hered. 95:498-502.

Xu, Y., X.X. Ouyang, H.Y. Zhang, G.B. Kang, Y.J. Wang, and H. Chen. 1999. Identification of a RAPD marker linked to fusarium wilt resistant gene in wild watermelon germplasm (Citrullus lanatus var. citroides). Acta Bot. Sin. 41:952-955.

Zhou, X.G. and K.L. Everts. 2004. Quantification of root and stem colonization of watermelon by Fusarium oxysporum $\mathrm{f}$. sp. niveum and its use in evaluating resistance. Phytopathology 94:832-841. 